The BMJ

Cite this as: $B M J$ 2021;372:m4932 http://dx.doi.org/10.1136/bmj.m4932 Published: 05 January 2021

\title{
How can I beat the January blues?
}

\section{The start of a new year can often be a difficult time, and this year it could be harder than ever. Abi Rimmer asks how doctors can help themselves cope}

Abi Rimmer

\section{Reminisce about good times}

Helen Garr, deputy director of NHS Practitioner Health, says, "Many of us will be greeting the new year exhausted and weary, and the January blues can be an additional challenge to maintaining our wellbeing. These five small steps can make a big difference.

"Firstly, embrace the blues (and the green). Spending time near water and in nature has positive impacts on mental and physical health. If you can't get outdoors, just looking at a picture of nature can help.

"The benefits of physical activity on body and mind are well known, so why not become part of a nationwide community and set yourself the challenge to 'get active every day to beat the blues away' with redtogether.co.uk.

"My third tip is to play. Harnessing creativity and spending time in play improves our reserves. Ask yourself what you used to enjoy doing as a child just for the sake of it and how you can reconnect with that now.

"Look forward and back. One of the best pieces of advice I was ever given was to always have something in the diary to look forward to. Conversely, recalling happy memories elicits positive feelings and can improve wellbeing. Dig out those old pictures and reminisce about happy moments in the past.

"Finally, if things feel overwhelming or difficult please know you are not alone. NHS Practitioner Health (www.practitionerhealth.nhs.uk) is here to care for you. Our service offers free, confidential mental health and addiction treatment and support to all doctors and dentists in England."

\section{Do what feels right for you}

Andrew Molodynski, community psychiatrist and BMA consultants' committee mental health lead, says, "Beating the blues is such a personal thing, whatever time of year they come. There are some things that help most of us though, such as keeping a lid on the booze, getting some exercise, and spending time with people we like. I wanted to share a few additional things that I've found helpful.

"Have a plan. Every year I write down on paper what I want to achieve and what I want to see happen and put it in my filing cabinet. When I'm frustrated, I get it out and it helps me refocus.

"Drop out of at least one virtual meeting a week (blame bad wi-fi) and go for a walk or do something different. Reconnect with patients and their families-it always works for me and reminds me why I'm here.
“Some negatives are important too. Don’t overdo it at work and get frustrated and burnt out. Don't spend time with people you don't like unless you must.

"More seriously, if you are really worried check in with someone-it doesn't matter who. They will not mind, quite the opposite.

"Finally, do what feels right for you. I had a really dark time some years ago. The thing that helped, apart from the love and care of people around me, was boxing. It led me to spend time-and do things-with people I would never have dreamt of and we raised lots of money for charity-well worth a few cracked ribs and broken noses."

\section{Do things you love}

Caroline Walker, psychiatrist and therapist at NHS Practitioner Health and founder of The Joyful Doctor, says, "January is a common time for doctors to struggle, but this year could be harder than most. Because of the coronavirus pandemic, we haven't had as much social interaction with our loved ones and friends over the Christmas period. All that lovely socialising would usually top us up and leave us grateful for a little down time come January. But this year, as the long nights continue, you may find yourself feeling more tired and jaded than usual.

"The good news? All those things that help with mood at other times will help in January. The first is connection. This is time spent (even online) with those people in our lives who make us smile, the people we genuinely look forward to spending time with.

"The next key element is light. Get out into natural daylight for a few minutes before midday if possible, or use a light lamp.

"The last element is movement. We tend to move less when it's cold and dark outside, so building some more movement into our day-to-day life in the winter months will make a big difference.

"Try googling 'deskercise' or 'desk yoga' if you're working from home, or put on your favourite song and dance about the house once a day. Whatever you do, make it easy and enjoyable-life is too short to do stuff you don't love.”

\section{Control what you can}

Sarah Goulding, coach for doctors and GP training programme director, says, "There are currently umpteen different reasons why we might be feeling glum. I'm going to focus on some techniques that work no matter what the cause. 
“There's evidence that the act of regularly recording what you are grateful for changes your brain. This can be something simple like your hot cup of coffee or listening to a song you love, or bigger themes such as family, housing, or health.

"Writing three short lines on our gratitude for the day can reduce the chance of developing anxiety or depression for the next six months. People doing regular gratitude practice also experience fewer symptoms of physical illness.

"There are many things outside our control right now and that can feel uncomfortable. Focusing on what is within your control is key. Where possible maximise your enjoyment or autonomy within those areas, for example what you read, the meals you eat, or what you watch on screen.

"Think about connection, and what that currently means to you. A few WhatsApp messages or comments online do not replace genuine human interaction. Many of us would benefit from altering how we safely experience connection.

"I have taken up writing letters again. Considering the recipient, asking a few thoughtful questions, and then imagining their happiness when opening the letter give me great joy. Likewise, walking and talking with a friend doubles the benefits of connection and the great wintery outdoors.

"So-in summary-gratitude, your zone of control, and connections are all ours to enjoy, irrespective of the external circumstances."

See also: Why we ... deskercise www.bmj.com/content/370/bmj.m3524 